\title{
Original
}

\section{The Inhibitory Effect of Amoxapine on Cytochrome P450 Enzyme Activity in Human Liver Microsomes}

\author{
Eriko Sakurai, Mariko Iwase, Norimitsu Kurata, \\ Tomoko Nagai, Hayato Hirashima, Yuki Nishimura \\ and Hajime YasuHaRA
}

\begin{abstract}
Amoxapine is a tricyclic antidepressant used for the treatment of psychotic depression. Psychotic depression is generally refractory to medical treatment and plural medicines are usually prescribed concurrently. The cytochrome P450 (CYP) enzyme has been implicated in the metabolism of several psychotropic drugs, and has clinical relevance relating to drug-drug interactions between psychotropic drugs and other common medicines. This study investigated the effects of amoxapine on the activities of CYP1A2, CYP2C9, CYP2C19, CYP2D6 and CYP3A4 using human liver microsomes. Amoxapine inhibited both CYP2D6 and CYP3A4 with apparent $\mathrm{Ki}$ values of 25.4 and $41.3 \mu \mathrm{M}$, respectively. The calculated $\mathrm{Ki}$ value for amoxapine was higher than the common therapeutic concentration range in plasma. Our study also revealed that inhibition of CYP2D6 and CYP3A4 enzyme activity by amoxapine is based on a competitive mechanism. Based on the $\mathrm{Ki}$ values observed in this study and the therapeutic amoxapine concentration in the blood, we conclude that amoxapine would not cause the severe drug-drug interaction mediated by CYP enzymes.
\end{abstract}

Key words : amoxapine, cytochrome P450, human liver microsomes, inhibition, psychotic depression Introduction

\section{Introduction}

Amoxapine is categorized as a second-generation tricyclic antidepressant (TCA $)^{1)}$. In several previous studies on the pharmacodynamic properties of amoxapine, potent noradrenaline reuptake inhibition ${ }^{2)}$, potent 5 -HT2 receptor antagonism $^{3)}$, and dopamine D2 receptor antagonism were reported ${ }^{4)}$. Based on this, amoxapine is prescribed for the treatment of psychomotor retardation and depressive mode ${ }^{5)}$. Amoxapine has antipsychotic action in addition to the antidepressant effect caused by the dopamine D2 receptor antagonism, and is therefore extremely effective for the treatment of psychotic depression ${ }^{6,7}$.

Psychotic depression is the term used to indicate severe depression complicated by psychotic features ${ }^{8)}$. The diagnostic category for psychotic depression is severe depressive episodes with psychotic symptoms (DSM IV) ${ }^{9}$. For the subcategory of psychotic symptoms, the patient should present with delusion, hallucinations, psychomotor agitation and retardation ${ }^{9)}$. 
The treatment of psychotic depression is different from other depression. TCA mono-therapy such as amoxapine alone is usually recommended for mildly affected patients, while combination therapy such as TCA together with other antipsychotic agents are commonly applied for patients with severe symptoms ${ }^{10)}$. However, in cases of symptomatic treatment for patients with complicated psychotic depression but without accompanying severe symptoms, combination therapies are also frequently required ${ }^{11)}$. In addition, it was reported recently that combination therapy for the treatment of psychotic depression is more effective than TCA mono-therapy ${ }^{12)}$. With the current trend of medication by using selective serotonin receptor antagonist (SSRI) and selective noradrenaline receptor antagonist (SNRI) for the treatment of psychotic depression, amoxapine remains one of the important antidepressant pharmacotherapies in the clinical setting.

Medication for patients with psychotic depression commonly involves multiple drugs used concurrently, including TCA, other antipsychotic drug and SSRI. TCA have been prescribed in the treatment of depression for a long time, and it is well known that metabolism of some of the TCA is mediated by the cytochrome P450 (CYP) enzyme ${ }^{13-19)}$. In the current multi-drug therapies used for patients with psychotic depression, there are many reports of drug-drug interactions between TCA and the other drugs described above $\mathrm{e}^{20,21,24)}$. However, most of the reports describe the inhibition of TCA metabolism by the co-administrated medicine. The inhibitory potential of TCA on CYP-mediated drug metabolism has not been extensively described, and risk assessments for multiple drug therapy in these patients have not considered factors such as unexpected changes in pharmacokinetic parameters and/or pharmacodynamics of the drugs. Amoxapine is frequency used for the treatment of psychotic depression and it is also commonly prescribed to be used concurrently with other antipsychotic drugs. However, there is no data evaluating the effect of amoxapine on CYP enzyme-mediated drug metabolism. Such information is necessary to properly assess the therapy risks and therefore to avoid adverse reactions in patients being treated for psychotic depression.

This study aimed to assess the effect of amoxapine on five CYP enzymes (CYP1A2, 2C9, 2C19, 2D6 and 3A4), which are important clinically due to their roles in drug metabolism. In addition, the influence of amoxapine metabolites on these CYP enzymes was determined.

\section{Materials and Methods}

\section{Chemicals and reagents}

Amoxapine was purchased from ICN Co., Ltd. (Irvine, CA, U.S.A). Bufuralol, 1'-hydroxybufuralol, S-warfarin, 7-hydroxywarfarin, 1'-hydroxymidazolam, ethoxyresorufin S-mephenytoin and 4-hydroxymephenytoin were purchased from Daiichi Pure Chemicals Co., Ltd. (Tokyo). Resorfin was obtained from Sigma Chemical Co. (St. Louis, MO, U.S.A). Midazolam was generously donated by Nippon Roche K.K. Inc (Osaka). $\beta$-nicotinamide adenine dinucleotide phosphate (NADPH), G-6-P and G-6-P DH were purchased from Oriental Yeast Co., Ltd. (Tokyo). All other chemicals and reagents used were of the highest commercially available quality.

\section{Enzyme sample}

Human liver microsomes (pooled fraction from 10 patients) were obtained from the Human and Animal Bridging Research Organization (Non-profit organization) (Lot NO. 
HPLM-8). The study protocol was approved by the Ethics Committee of Showa University, School of Medicine.

\section{Analytical procedure of CYP enzyme activity}

The inhibitory effects of amoxapine on the metabolism of five different CYP isoformspecific substrates were studied: ethoxyresorufin O-deethylation for CYP1A2, S-warfarin 7-hydroxylation for CYP2C9, S-mephenytoin 4'-hydroxylation for CYP2C19, bufuralol 1'-hydroxylation for CYP2D6 and midazolam 1'-hydroxylation for CYP3A4.

\section{Ethoxyresorufin. O-deethylation activity}

The incubation mixtures (final volume, $500 \mu 1$ ) consisting of a NADPH generating system (0.6 mM NADPH, $5 \mathrm{mM} \mathrm{G-6-P}$ and $0.5 \mathrm{U}$ G-6-P DH), $200 \mu \mathrm{g}$ of microsomal protein, $2 \mu \mathrm{M}$ ethoxyresorufin and $5 \mathrm{mM} \mathrm{MgCl}_{2}$ and with or without amoxapine in $128 \mathrm{mM}$ potassium phosphate buffer $(\mathrm{pH} 7.4)$ were incubated at $37^{\circ} \mathrm{C}$ for 15 minutes. The enzymatic reaction was terminated by $2 \mathrm{~mL}$ of methanol on ice. The samples were centrifuged at $1,800 \times \mathrm{g}$ for $10 \mathrm{~min}$. The resulting supernatant was analyzed by fluorescence spectrophotometer (F-2000, HITACHI Co., Ltd. Tokyo). Fluorescence detection was performed at wavelengths of 530 and $585 \mathrm{~nm}$, excitation and emission, respectively. The enzyme activity was calculated from the resorufin formation rate from ethoxyresorufin.

\section{S-warfarin 7-hydroxylation activity}

The incubation mixtures (final volume, $250 \mu \mathrm{l}$ ) consisted of a NADPH generating system ( $1 \mathrm{mM}$ NADPH, $8 \mathrm{mM}$ G-6-P and 0.5U G-6-P DH), $200 \mu \mathrm{g}$ of microsomal protein, $5 \mu \mathrm{M}$ S-warfarin and $4 \mathrm{mM} \mathrm{MgCl}$ and with or without amoxapine in $54 \mathrm{mM}$ potassium phosphate buffer ( $\mathrm{pH} \mathrm{7.4).} \mathrm{The} \mathrm{mixture} \mathrm{was} \mathrm{incubated} \mathrm{at} 37^{\circ} \mathrm{C}$ for 30 minutes and enzymatic reaction was terminated by $10 \mu \mathrm{L}$ of $60 \%$ perchloric acid on ice. The samples were centrifuged at $12,000 \times \mathrm{g}$ for $5 \mathrm{~min}$ and the resulting supernatant was applied onto an HPLC system. The separation of 7-hydroxywarfarin was performed using a CAPCELLPAK C18 SG120 (4.6 $\mathrm{mm} \times 15 \mathrm{~cm}$ ) ODS column (Shiseido Co., Tokyo), and elution was performed with $0.5 \%$ phospholic acid : acetonitril $(62: 38)$. The flow rate of the mobile phase was $1.2 \mathrm{~mL} / \mathrm{min}$ and 7-hydroxywarfarin was detected by a fluorescence detector at wavelengths $315 \mathrm{~nm}$ and $415 \mathrm{~nm}$, excitation and emission, respectively. CYP2C9 activity was calculated from the 7-hydroxywarfarin formation rates.

\section{S-mephenytoin 4'-hydroxylation activity}

The incubation mixtures (final volume, $500 \mu 1$ ) consisting of a NADPH generating system ( $1 \mathrm{mM}$ NADPH, $8 \mathrm{mM} \mathrm{G-6-P}$ and $0.5 \mathrm{U}$ G-6-P DH), $200 \mu \mathrm{g}$ of microsomes, 100 $\mu \mathrm{M}$ S-mephenytoin and $4 \mathrm{mM} \mathrm{MgCl}_{2}$ and with or without amoxapine in $80 \mathrm{mM}$ potassium phosphate buffer ( $\mathrm{pH} \mathrm{7.4)}$ were incubated at $37^{\circ} \mathrm{C}$ for 60 minutes. The enzymatic reaction was terminated by $200 \mu \mathrm{l}$ of acetonitril on ice. Phenobarbital $(0.1 \mu \mathrm{g})$ was spiked as an internal standard and the major metabolite, 4'-hydroxymephenytoin, was extracted with 3 $\mathrm{mL}$ of dichlomethane. The dichrolomethane extracts were evaporated under a steam of dry nitrogen gas at $35^{\circ} \mathrm{C}$. The resulting residue was reconstituted with the mobile phase and applied onto an HPLC. The separation of 4'-hydroxymephenytoin was performed using a CAPCELLPAK C18 AG120 $(4.6 \mathrm{~mm} \times 25 \mathrm{~cm})$ ODS column (Shiseido Co., Ltd., Tokyo). 
The flow rate of the mobile phase was $1 \mathrm{ml} / \mathrm{min}$ and $\mathrm{UV}$ absorbance was monitored at 204 $\mathrm{nm}$. The enzyme activity was calculated from the 4'-hydroxymephenitoin formation rates.

\section{Bufuralol 1'-hydroxylation activity}

The incubation mixtures (final volume, $150 \mu \mathrm{l}$ ) consisting of a NADPH generating system ( $1 \mathrm{mM}$ NADPH, $8 \mathrm{mM}$ G-6-P and 0.4U G-6-P DH), $15 \mu \mathrm{g}$ of microsomal protein, $10 \mu \mathrm{M}$ bufuralol and $500 \mu \mathrm{M} \mathrm{MgCl}_{2}$ and with or without amoxapine in $90 \mathrm{mM}$ sodiumpotassium phosphate buffer ( $\mathrm{pH} \mathrm{7.4)}$ was incubated at $37^{\circ} \mathrm{C}$ for 15 minutes. The enzymatic reaction was terminated by $15 \mu 1$ of $60 \%$ perchloric acid on ice. The resulting samples were centrifuged at $12,000 \times \mathrm{g}$ for $5 \mathrm{~min}$. The supernatant was applied onto an HPLC system. The separation of 1'-hydroxybufuralol was carried out using an CAPCELLPAK C18 SG120 $(4.6 \mathrm{~mm} \times 25 \mathrm{~cm})$ ODS column (Shiseido Co., Ltd, Tokyo). Elution was performed with $20 \mathrm{mM} \mathrm{NaClO}$ ( $\mathrm{pH}^{2.5)}$ : acetonitrile $(70: 30)$. The flow rate of the mobile phase was $1 \mathrm{ml} / \mathrm{min}$ and 1'-hydroxybufuralol was detected by fluorometric detection wavelengths at $252 \mathrm{~nm}$ and $302 \mathrm{~nm}$, excitation and emission, respectively. Enzyme activity was calculated from the 1'-hydroxybufuralol formation rates from bufuralol.

\section{Midazolam 1'-hydroxylation activity}

The incubation mixtures (final volume, $200 \mu \mathrm{l}$ ) consisting of a NADPH generating system ( $1 \mathrm{mM}$ NADPH, $8 \mathrm{mM}$ G-6-P and 0.5U G-6-P DH), $100 \mu \mathrm{g}$ of microsomal protein, $10 \mu \mathrm{M}$ midazolam and $4 \mathrm{mM} \mathrm{MgCl}_{2}$ and with or without amoxapine in $80 \mathrm{mM}$ potassium phosphate buffer ( $\mathrm{pH} \mathrm{7.4)}$ were incubated at $37^{\circ} \mathrm{C}$ for 5 minutes. The enzymatic reaction was terminated by $200 \mu \mathrm{L}$ of methanol-acetonitrile on ice $(35: 21)$. Nitrazepam (0.75 $\mathrm{nmol}$ ) was spiked as an internal standard and the reaction mixture was centrifuged at $12,000 \times \mathrm{g}$ for $10 \mathrm{~min}$. The resulting supernatant was applied onto an HPLC system. The separation of 1'-hydroxymidazolam was carried out using a CAPCELLPAK C18 SG120 (4.6 $\mathrm{mm} \times 25 \mathrm{~cm}$ ) ODS column (Shiseido Co., Ltd, Tokyo). Elution was performed with $10 \mathrm{mM}$ potassium phosphate buffer $(\mathrm{pH} 7.4)$ : methanol: acetonitrile $(66: 17: 17)$. The flow rate of the mobile phase was $1 \mathrm{ml} / \mathrm{min}$ and UV absorbance was monitored at $220 \mathrm{~nm}$. The enzyme activity was calculated from the 1'-hydroxymidazolam formation rates from midazolam.

\section{HPLC system}

HPLC analyses of extracts of microsomal incubations were performed using a JASCO HPLC system (JASCO, Tokyo) with an intelligent pump (880-PU), automatic sample injector (851-AS), degasser (880-50) and system controller (802-SC). Detection was carried out using an SPD-6A (Shimadzu Co., Kyoto) and L7485 (Hitachi Co., Ltd, Tokyo), UV-detector and fluorescence detector. Data calculation was performed on a C-R7A integrator (Shimadzu Co., Kyoto).

\section{IC50 determinations}

IC50 values of amoxapine on CYP enzymes were calculated by the concentrationinhibition relationship and determined graphically from a plot of \% control activity against amoxapine concentration. 


\section{Determination of inhibition constant}

Dixon plot analysis was employed to determine the inhibition constant (Ki value) of amoxapine on CYP2D6 and CYP3A4. Amoxapine was applied to the incubation mixture at a concentration of between 1 and $1000 \mu \mathrm{M}$ as illustrated in Figures 2 and 3. Substrate concentrations for bufuralol and midazolam were 5, 10 and $20 \mu \mathbf{M}$.

\section{Preincubation-dependent inhibition of amoxapine on CYP enzymes}

To evaluate the inhibitory effect of amoxapine metabolites on CYP enzymes activity, a pre-incubation study was conducted. Amoxapine concentrations of $50 \mu \mathbf{M}$ for CYP1A2, 2C9, 2C19, and 3A4, and $10 \mu \mathrm{M}$ for CYP2D6, were used. Pre-incubations were carried out for 10 to $30 \mathrm{~min}$, with or without the NADPH generating system, before commencement of each CYP-dependent enzyme reaction.

\section{Results}

\section{Inhibitory effects of amoxapine on CYP enzyme activities in human liver microsomes}

To evaluate the inhibitory potency of amoxapine on CYP enzymes, the concentrationinhibition relationship was examined. Amoxapine was a potent inhibitor of CYP2D6 and 3A4 activity with apparent IC50 values of 25.37 and $76.87 \mu \mathrm{M}$, respectively. In contrast, amoxapine demonstrated only a weak inhibitory effect on CYP2C9 and CYP2C19 enzyme with IC50 values of 236.69 and $148.40 \mu \mathrm{M}$, respectively. A negligible inhibitory effect was observed on CYP1A2 (Fig. 1).

\section{Dixon plot analysis of the effect of amoxapine on CYP2D6 in human liver microsomes}

Dixon Plot analysis was also performed to confirm the inhibitory potency and mechanism of action of amoxapine on CYP2D6 and CYP3A4. Amoxapine was a competitive inhibitor

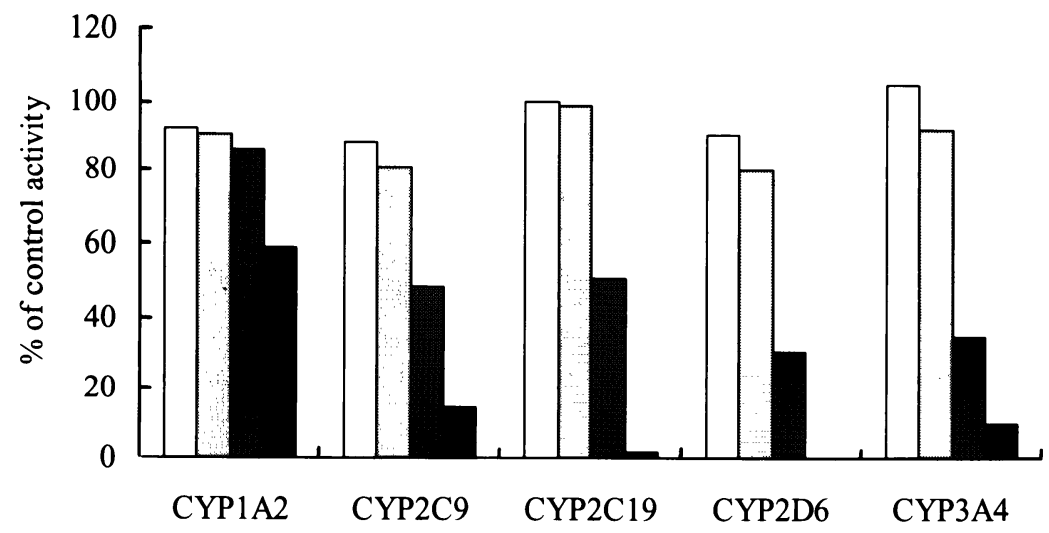

$$
\square 1 \mu \mathrm{M} \square 10 \mu \mathrm{M} \square 100 \mu \mathrm{M} \square 1000 \mu \mathrm{M}
$$

Fig. 1. Inhibitory effects of amoxapine on CYP enzyme activity in human liver microsomes.

Each column indicates the amoxapine concentration described in the figure.

The data points represent the average of duplicate determinations. 


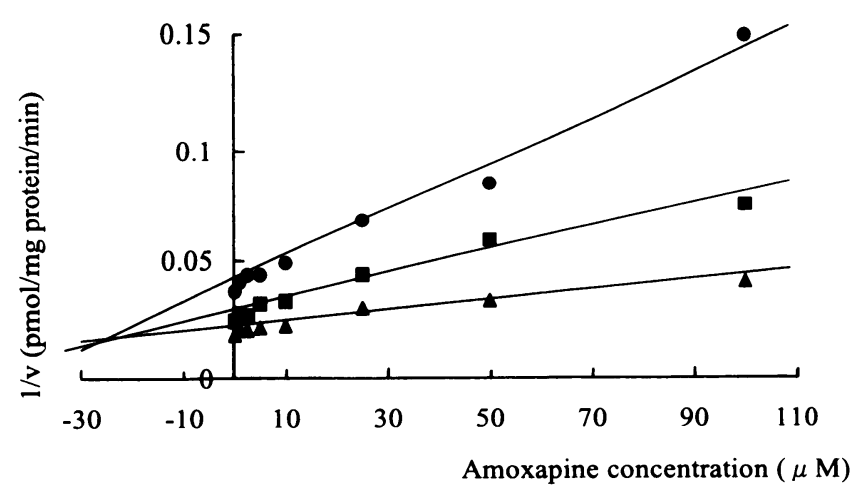

- $5 \mu \mathrm{M} \backsim 10 \mu \mathrm{M} \triangle 20 \mu \mathrm{M}$

\section{CYP3A4}

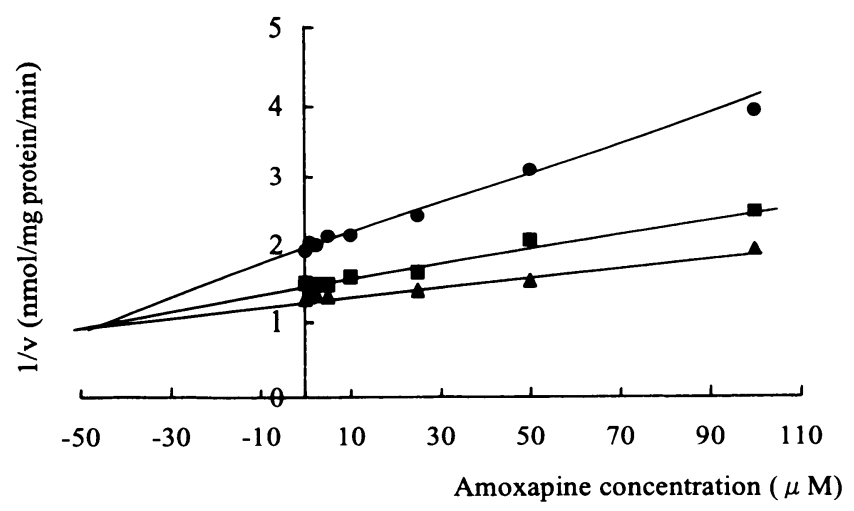

- $5 \mu \mathrm{M} \backsim 10 \mu \mathrm{M} \triangle 20 \mu \mathrm{M}$

Fig. 2. Dixon plot analysis of amoxapine on CYP2D6 and CYP3A4 in human liver microsomes.

The human liver microsomes were incubated with 5,10 , and $20 \mu \mathbf{M}$ of bufuralol in CYP2D6 and midazolam in CYP3A4.

Each data point represents the average of duplicate determinations.

The apparent $\mathrm{Ki}$ value was calculated by using the linear regression analysis method.

of both CYP2D6- and CYP3A4-mediated enzyme reactions with calculated $\mathrm{Ki}$ values of 25.4 and $41.3 \mu \mathrm{M}$, respectively (Fig. 2 ).

Influence of pre-incubation with amoxapine on CYP enzyme activity in human liver microsomes

To evaluate the participation of amoxapine metabolites in the inhibition of CYP enzyme-mediated drug metabolism, pre-incubation studies were performed. However, no significant gain in the inhibitory potency of amoxapine was observed (Fig. 3). 


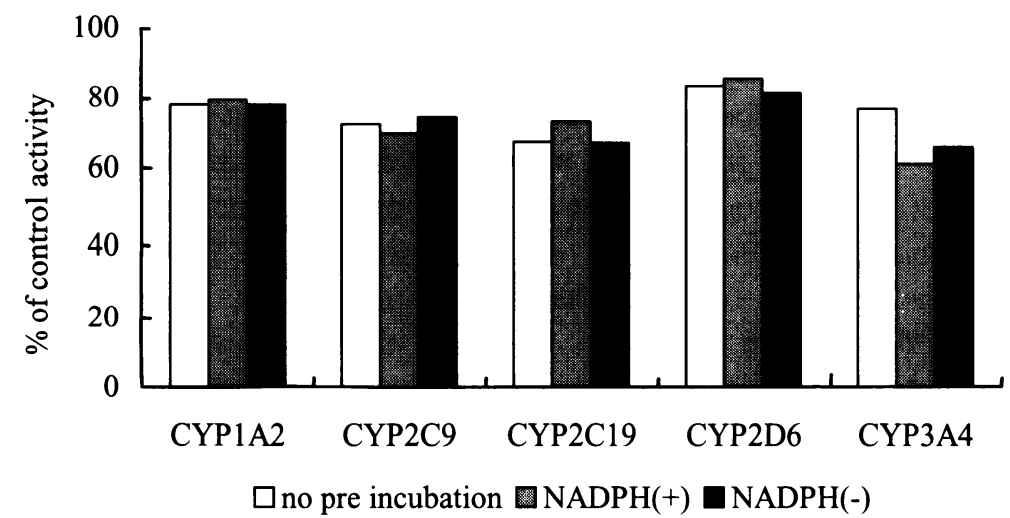

Fig. 3. Influence of preincubation with amoxapine on CYP enzymes activity in human liver microsomes.

Amoxapine was preincubated for $30 \mathrm{~min}$, with or without NADPH, prior to commencement of CYP-dependent enzyme reaction.

The final concentration of amoxapine in the incubation mixture was $50 \mu \mathrm{M}$ in CYP1A2, CYP2C9, CYP2C19 and CYP3A4, and $10 \mu \mathrm{M}$ in CYP2D6.

Each data point represents the average of duplicate determinations.

\section{Discussion}

In the present study, we investigated the inhibitory potency of amoxapine on the CYP enzymes, CYP1A2, 2C9, 2C19, 2D6 and 3A4. Competitive inhibition was observed with CYP2D6 and 3A4, while only a marginal effect was observed with CYP1A2, 2C9 and 2C19. In general, TCAs are mainly metabolized to $\mathrm{N}$-demethylated and hydroxylated forms ${ }^{13-19)}$. The hydroxylation reaction is mainly mediated by CYP2D6 ${ }^{13,14,17,19)}$, and several CYPs are involved in the $\mathrm{N}$-demethylation ${ }^{15,16,18,19)}$. Venkatakrishnan et al. reported that nortiptyline, classified in the same TCA group as amoxapine, is metabolized to 10-hydroxynortriptyline by CYP2D6 with an apparent $\mathrm{Km}$ value of $2.1 \mu \mathrm{M}$ and CYP3A4 with an apparent $\mathrm{Km}$ value of $37.4 \mu \mathrm{M}^{13)}$. In addition, amitriptyline $\mathrm{N}$-demethylation is mediated by CYP3A4, CYP1A2, CYP2D6, and CYP2C ${ }^{16)}$. It is also reported that amoxapine is metabolized to 7-hydroxyamoxapine and 8-hydroxyamoxapine ${ }^{2,22}$, however there is not much information about the corresponding enzyme mediating this biotransformation. The data presented here showed that amoxapine inhibits the CYP2D6 and CYP3A4 enzymes competitively. The major metabolic pathway converting amoxapine to 7- or 8- hydroxyamoxapine is aromatic hydroxylation, as for other TCAs. Together with results from other studies, our results indicate that 7- or 8- hydroxylation of amoxapine may be catalyzed mainly by CYP2D6 and partially by CYP3A4.

It has been reported that TCAs are metabolized by several CYP isozymes ${ }^{13-19)}$ and also that several drug-drug interaction between TCAs and co-administered medicine occur $^{20,21,23-25)}$. Bergstom et $a l^{23)}$ reported that fluoxetine had potently lowered the systemic clearance of imipramine by $1 / 10$. Another report showed that paroxetine administration prolongs the elimination half life of imipramine by approximately $50 \%{ }^{21)}$. Inhibition of CYP enzyme activity by TCA has also been reported, particularly for CYP2D6, with apparent $\mathrm{Ki}$ values as follows: clomipramine $(2.2 \mu \mathbf{M})$, desipramine $(2.3 \mu \mathbf{M})$ and 
amitriptyline $(4.0 \mu \mathrm{M})^{26)}$. Shin et al. also reported that CYP2D6 activity was inhibited by amitriptyline, imipramine, nortriptyline and desipramine with apparent $\mathrm{Ki}$ values of 31.0, 28.6, 7.9 and $12.5 \mu \mathrm{M}$, respectively ${ }^{27)}$. Based on these previous studies, the apparent $\mathrm{Ki}$ value of amoxapine obtained from the present study is consistent with other TCAs, suggesting an inhibitory effect on CYP2D6-mediated drug metabolism.

Since TCAs inhibit CYP2D6-mediated enzyme activity ${ }^{26,27)}$, it is not surprising that numerous interactions between TCAs and commonly used drugs, which are categorized as substrates of CYP2D6, has been observed. However, the exact inhibitory potency of TCAs on CYP2D6 has not been extensively studied. It has been reported that fluoxetine and paroxetine, which are SSRIs, also inhibit CYP2D6 activity in vivo ${ }^{21,23,28)}$ and in vitro ${ }^{26)}$, with $\mathrm{Ki}$ values of 0.6 and $0.15 \mu \mathrm{M}$, respectively. These $\mathrm{Ki}$ values are lower than the $\mathrm{Ki}$ values of TCAs described above. Furthermore, fluoxetine and paroxetine are widely distributed throughout body tissues ${ }^{21,29)}$, and have a Cmax level of approximately $160^{29)}$ and $40 \mathrm{nM}^{21)}$, respectively. These blood concentrations are close to their apparent $\mathrm{Ki}$ values estimated in vitro. In contrast, imipramine, which also is widely distributed throughout body tissue (Vd value $=28-61 \mathrm{l} / \mathrm{kg}$ ), has a Cmax value of approximately $70 \mathrm{nM}^{21)}$, which is lower than the $\mathrm{Ki}$ value calculated from in vitro studies. Although it is hard to extrapolate these data directly to in vivo drug-drug interactions, imipramine probably does not affect the metabolism of the substrate of CYP2D6.

Amoxapine has been widely prescribed to patients with depression for a long time. However, there is scarce data on the drug-drug interactions between amoxapine and co-administrated medicines. Amoxapine is usually administered orally with a dose regimen of $25-75 \mathrm{mg}$ daily in Japan. In serious patients, the dosage may be increased up to $300 \mathrm{mg}$ daily $^{2)}$. Amoxapine is widely distributed throughout all tissues of the body ${ }^{222}$. Greenblatt et al reported that the concentration of amoxapine in tissue was 10 times higher than the plasma concentration $5 \mathrm{~min}$ after the intravenous administration in animal experiments ${ }^{30}$. Amoxapine reached maximal serum levels of $0.14 \mu \mathrm{M}$ between 1 and $1.5 \mathrm{hr}$ after a single oral dosage $(50 \mathrm{mg})^{2,22)}$. Similar to other TCAs, amoxapine takes several weeks to have a therapeutic effect. During this long-term period, accumulation of amoxapine in the body tissues may occur. However, the apparent $\mathrm{Ki}$ values of amoxapine for CYP2D6 and CYP3A4 estimated in the present study were higher than the drug concentration in plasma commonly using for the treatment of psychotic depression. Therefore, these results indicate that amoxapine might not inhibit the CYP2D6 and CYP3A4 enzyme-mediated drug metabolism of the co-administered medicines in vivo.

On the other hand, it has been reported that amoxapine is metabolized to the major metabolites, 7-hydroxyamoxapine and 8-hydroxyamoxapine in the liver ${ }^{222}$. These metabolites have pharmacological effects similar to amoxapine ${ }^{2,22)}$. The active metabolite, 8hydroxyamoxapine appears immediately in plasma and is eliminated quite slowly from the blood, with an average elimination half-life of $30.8 \mathrm{hr}^{22)}$. We proposed that these metabolites might have an influence on the CYP enzyme-mediated drug metabolism. Unfortunately, it is impossible to obtain these metabolites. Therefore, we tried a pre-incubation study to evaluate the effects of these metabolites on CYP enzyme activity. The inhibitory potency of amoxapine was not increased by pre-incubation with or without NADPH. This result suggested that amoxapine metabolites do not affect the CYP enzyme-mediated drug metabolism. However, the technique used could not adequately represent the production of 
amoxapine metabolites in vivo in type or amount, and further study will be needed to properly assess the effect of active metabolites on CYP enzyme activity.

In conclusion, amoxapine inhibits the catalytic activity of CYP2D6 and CYP3A4 in a competitive manner. The inhibitory potency of amoxapine on CYP2D6 was comparable to the other first-generation TCAs reported previously ${ }^{26,27)}$, indicating that CYP2D6 may be involved in amoxapine metabolism. In addition, amoxapine metabolism may be inhibited by the drugs administered concurrently, which are metabolized by the CYP2D6 enzyme. However, comparison of the $\mathrm{Ki}$ values observed in this study and the therapeutic amoxapine concentration in the blood suggests that amoxapine would not inhibit the metabolism of co-administrated medicines.

\section{References}

1) Coccaro EF and Siever LJ : Second generation antidepressants: A comparative review. J Clin Pharmacol 25 : 241-260 (1985)

2) Kinney JL and Evans RL: Evaluation of amoxapine. Clin Pharm 1:417-424 (1982)

3) Wander TJ, Nelson A, Okazaki $\mathbf{H}$ and Richelson E: Antagonism by antidepressants of serotonin S1 and S2 receptors of normal human brain in vitro. Eur J Pharmacol 132 : 115-121 (1986)

4) Richelson E and Nelson A : Antagonism by antidepressants of neurotransmitter receptor of normal human brain in vitro. J Pharmacol Exp Ther 230 : 94-102 (1984)

5) Takahashi R, Sakuma A, Hara T, Kazamatsuri H, Mori A, Saito Y, Murasaki M, Oguchi T, Sakurai Y, Yuzuriha T, Takemura $\mathbf{M}$, Kurokawa $\mathbf{H}$ and Kurita $\mathbf{H}$ : Comparison of efficacy of amoxapine and imipramine in a multi-clinic double-blind study using the WHO schedule for a standard assessment of patients with depressive disorders. J Int Med Res $7: 7-18$ (1979)

6) Anton RF and Sexauer JD : Efficacy of amoxapine in psychotic depression. Am J Psychiatry 140:1344-1347 (1983)

7) Anton RF and Burch Jr EA : Amoxapine versus amitriptyline combined with perphenazine in the treatment of psychotic depression. Am J Psychiatry 147:1203-1208 (1990)

8) Wheeler VJA, Mortimer AM and Tyson PJ: Somatic treatment of psychotic depression: Review and recommendations for practice. J Clin Psychopharmacol 20 : 504-519 (2000)

9) Diagnostic and statistical manual of mental disorders, 4th edition, American Psychiatric Association, Washington, D.C. (1994)

10) Crismon ML, Trivedi M, Pigott TA, Rush AJ, Hirschfeld RMA, Kahn DA, Nelson JC, Nierenberg AA, Sackeim HA and Thase ME: The Texas Medication Algorithm Project: Report of the Texas Consensus Conference Panel on Medication Treatment of Major Depressive Disorder. J Clin Psychiatry 60:142-156 (1999)

11) Chan CH, Janicak PG, Davis JM, Altman E, Andriukaitis S and Hedeker D : Response of psychotic and nonpsychotic depressed patients to tricyclic antidepressants. J Clin Psychiatry 48 : 197-200 (1987)

12) Spiker DG, Weiss JC, Dealy RS, Griffin SJ, Hanin I, Neil JF, Perel JM, Rossi AJ and Soloff PH: The pharmacological treatment of delusional depression. Am J Psychiatry 142 : 430-436 (1985)

13) Venkatakrishnan K, von Moltke LL and Greenblatt DJ : Nortriptyline E-10-hydroxylation in vitro is mediated by human CYP2D6 (high affinity) and CYP3A4 (low affinity): implications for interactions with enzyme-inducing drugs. J Clin Pharmacol 39 : 567-577 (1999)

14) Brosen $\mathrm{K}$ and Gram LF : First-pass metabolism of imipramine and desipramine : impact of the sparteine oxidation phenotype. Clin Pharmacol Ther $43: 400-406$ (1988)

15) Lemoine A, Gautier JC, Azoulary D, Kiffel L, Belloc C, Guengerich FP, Maurel P, Beaune P and Leroux JP: Major pathway of imipramine metabolism is catalyzed by cytochromes P-450 1 A2 and P-450 3A4 in human liver. Mol Pharmacol 43 : 827-832 (1993)

16) Venkatakrishnan K, Greenblatt DJ, von Moltke LL, Schmider J, Harmatz JS and Shader RI: Five distinct human cytochromes mediate amitriptyline $\mathrm{N}$-demethylation in vitro: Dominance of CYP2C19 and 3A4. J Clin Pharmacol 38 : 112-121 (1998)

17) Nielsen KK, Flinois JP, Beaune $P$ and Brosen $K$ : The biotransformation of clomipramine in vitro, identification of the cytochrome P450s responsible for the separate metabolic pathways. $J$ Pharmacol Exp Ther 277 : 1659-1664 (1996)

18) Brachtendorf L, Jetter A, Beckurts KT, Holscher AH and Fuhr U : Cytochrome P-450 enzymes contributing 
to demethylation of maprotiline in man. Pharmacol Toxicol $90: 144-149$ (2002)

19) Koyama E, Chiba K, Tani $M$ and Ishizaki T : Identification of human cytochrome $P 450$ isoforms involved in the stereoselective metabolism of mianserin enantiomers. J Pharmacol Exp Ther 278:21-30 (1996)

20) Spina E, Pollicino AM, Avenoso A. Campo GM and Caputi AP : Fluvoxamine-induced alteractions in plasma concentrations of imipramine and desipramine in depressed patients. Int J Clin Pharm Res 13 : 167-171 (1993)

21) Albers LJ, Reist C, Helmeste D, Vu R and Tang SW : Paroxetine shifts imipramine metabolism. Psychiatry Res 59: 189-196 (1996)

22) Calvo B, Gracia MJ, Pedraz JL, Marino EL and Dominguez-Gil A: Pharmacokinetics of amoxapine and its active metabolites. Int J Clin Pharmacol Ther Toxicol 23 : 180-185 (1985)

23) Bergstrom RF, Peyton AL and Lemberger L: Quantification and mechanism of the fluoxetine and tricyclic antidepressant interaction. Clin Pharmacol Ther 51 : 239-248 (1992)

24) Alderman J, Preskorn SH, Greenblatt DJ, Harrison W, Penenberg D, Allison J and Chung M: Desipramine pharmacokinetics when coadministered with paroxetine or sertraline in extensive metabolizers. $J$ Clin Psychopharmacol $17: 284-291$ (1997)

25) Belle DJ, Ernest CS, Sauer JM, Smith BP, Thomasson HR and Witcher JW: Effect of potent CYP2D6 inhibition by paroxetine on atomoxetine pharmacokinetics. J Clin Pharamacol 42 : 1219-1227 (2002)

26) Crewe HK, Lennard MS, Tucker GT, Woods FR and Haddock RE: The effect of selective serotonine re-uptake inhibitors on CYP2D6 activity in human liver microsomes. Br J Clin Pharmacol 34: 262-265 (1992)

27) Shin JU, Park JY, Kim MJ, Shon JH, Yoon YR, Cha IJ, Lee SS, Oh SW, Kim SW and Flockhart DA: Inhibitory effects of tricyclic antidepressants(TCAs) on human cytochrome P450 enzymes in vitro: Mechanism of drug interaction between TCAs and phenytoin. Drug Metab Dispos 30:1102-1107 (2002)

28) Otton SV, Wu D, Joffe RT, Cheung SW and Sellers EM: Inhibition by fluoxetine of cytochrome P450 2 D6 activity. Clin Pharmacol Ther 53 : 401-409 (1993)

29) Cheer SM and Goa KL: Fluoxetine. A review of its therapeutic potential in the treatment of depression associated with physical illness. Drugs 61:81-110 (2001)

30) Greenblatt EN, Hardy RA and Kelly RG: Amoxapine. Pharmacol Biochem Prop Drug Subst 2: 1-18 (1979)

[Received November 10, 2004 : Accepted December 15, 2004] 